\title{
The Influence of Reference Group, Brand Image, and Internet Marketing on Buying Decision
}

\author{
Moh Khotib ${ }^{1}$, Santitriyaningrum Soebandi, SE.,M.Com ${ }^{2}$ \\ Narotama University \\ Mohkhotib7@gmail.com
}

\begin{abstract}
: with the development of technology and information as well as the rapid growth and spread of the population today, has an impact on all aspects of human life. One of them is to communicate fluently in conveying information. In marketing products there are several strategies used, such as the use of reference groups, brand image and internet marketing in determining purchasing decisions. The purpose of this study was to determine the effect of reference groups, brand image and internet marketing on purchasing decisions on As card products. The sampling method uses random sampling, with the method of multiple linear linear analysis the research shows that the reference group, brand image and internet marketing have an effect on the As card purchase decision. In this research, it is expected to be able to give a new view in marketing products, especially among the community.
\end{abstract}

Keywords: reference group, brand image, internet marketing, purchasing decisions.

\section{INTRODUCTION}

With the development of technology and information and the rapid growth and spread of population today, it has an impact on all aspects of human life. One of them is to communicate smoothly with such demands, making the companies engaged in telecommunications competing to issue SIM (subcider identity module) based on GSM technology. The following are the types of GSM operators in Indonesia, namely Tri, Indosat, Xl, and Telkomsel (As) with the number of GSM cards being marketed which means flexibility for consumers.

The increasing trend of smartphone use in the community has made the growth of the internet in Indonesia continue to increase continuously. From the research data released by the Indonesian internet network user association (APJII) in 2017, it provides a clear picture of the trends in international users in Indonesia. According to MARKPLUS, the number of internet users in Indonesia in 2017 has reached 143.26 million people. The average penetration of internet users in major cities in Indonesia in 2014 was still 30-40 percent, whereas in 2017 MARKPLUS insight explained the increase in the range of 50-69 percent.

Based on the explanation above, it was seen that the level of mobile and internet usage was greatly influenced by consumer demographic factors that are inseparable from consumer behavior so that buying decisions are influenced by two factors, namely internal and external. In the external environment in the mobile world there are many communities in the virtual world that will be entered by marketers so that the reference group plays an important role in the process of purchasing decisions.

\section{Research Objectives}

The purpose of the study is to find out whether:

1. to determine the influence of reference groups, brand image, and internet marketing simultaneously on buyer decisions.

2. to find out about the positive status of the purchase decision.

3. to know the positive brand image of purchasing decisions

4. to know positive internet marketing on purchasing decisions. 


\section{LITERATURE REVIEW}

\section{Marketing}

Assuari'smanagement (2013: 12), the notion of marketing management is the activity of analyzing, planning, implementing, and controlling programs arranged in the formation, development, and maintenance of profits and exchanges / transactions through targets with the hope of achieving organizational goals.

\section{Reference group}

In a marketing perspective, a reference / reference group is a group that serves as a reference for a person in a buyer's decision and consumption.

\section{Brand image}

Tjiptono (2011: 112), brand image or brand description is a description of the association and consumer confidence in a particular brand. A number of quantitative and qualitative techniques have been developed to form consumer perceptions and associations for a particular brand.

\section{Internet marketing}

Kotler and Armstrong (2008: 237) internet marketing is a business enterprise to market products and services and build customer relationships through the internet.

\section{Conceptual framework}

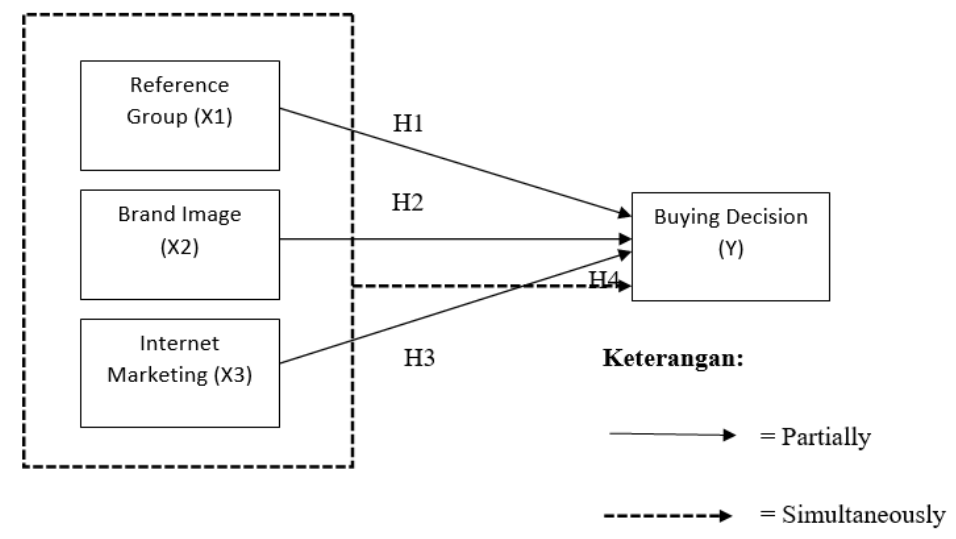

\section{RESEARCH METHODS}

\section{Types of research}

This research approach uses a quantitative approach to examine certain populations or samples, sampling techniques are generally done randomly, data collection uses research instruments, analysis which is quantitative or statistical in order to test what has been set. Sugiyono (2013) The

\section{Place and time of the implementation}

Of this research was conducted at schools, campuses and offices. The time for conducting research for two months. starting from December 2018 to January 2019.

\section{Population and sample}

The population used in this study were school children, students, and workers. The sample in this study were 160 respondents.

\section{Methods of data analysis}

Because this research is quantitative research, the data obtained from respondents through questionnaires are coded according to a 1-5 Likert scale and then tabulated using statistical analysis with the SPSS computer program. The collected data will be analyzed with several stages, first the 
validity test and the reliability of the research instrument, the classic assumption test in the form of normality test, multicollinearity test and hetereschedaticity test. Terakir tested the multiple linear regression model consisting of determination coefficient test, simultaneous significant test (F test) and partial significance test (T test) with the help of SPSS software version 18.

\section{RESULT AND DISCUSSION}

Validity Test

Table 1.Validity Test Results

Item-Total Statistics

\begin{tabular}{|l|r|r|r|r|}
\hline & $\begin{array}{c}\text { Scale Mean if } \\
\text { Item Deleted }\end{array}$ & $\begin{array}{c}\text { Scale Variance if } \\
\text { Item Deleted }\end{array}$ & $\begin{array}{c}\text { Corrected } \\
\text { Item-Total } \\
\text { Correlation }\end{array}$ & $\begin{array}{c}\text { Cronbach's } \\
\text { Alpha if Item } \\
\text { Deleted }\end{array}$ \\
\hline X1.1 & 59.112500 & 56,390 & .200 & .838 \\
X1.2 & 58.418750 & 52,559 & .514 & .819 \\
X1.3 & 58,075000 & 52,850 & .603. & 815 \\
X1.4 & 58.075000 & $53,592$. & 511. & 818 \\
X2.1 & 58.575000 & $52,296$. & 468. & 822 \\
X2.2 & 58.356250 & $52,596$. & 492. & 820 \\
X2.3 & 58.293750 & $52,234$. & 540 & .817 \\
X3.1 & 58.525000 & 51,018 & .546 & .816 \\
X3.2 & 58.381250 & 51.910 & .561. & 816 \\
X3.3 & 58.162500 & 52.904. & 592. & 816 \\
X3.4 & 58.212500 & 52,684 & .552. & 817 \\
X3.5 & 58.143750 & 57,004 & .246 & .833 \\
Y1.1 & 58.612500 & 53,610 & .364 & .829 \\
Y1.2 & 58.337500 & 56,175 & .833 & .261 \\
Y1.3 & $55,632.314 .830$ & & & 58.268750 \\
Y1.4 & $55,268.359 .828$ & & & 58.200000 \\
\hline
\end{tabular}

Validity test on a variable reference group $(\mathrm{X} 1)$, brand image $\left(\mathrm{X}_{2}\right)$, internet marketing $\left(\mathrm{X}_{3}\right)$, and purchasing decisions ( $\mathrm{Y}$ ) can be seen above, it appears that the value of $\mathrm{R}_{\text {calculates }}$ each item exceeds that of $\mathrm{R}_{\text {table }}$ 1.557. This means that each item statement can be declared valid.

\section{Test Reliability}

Testing the Cronbach's alpha statistics, the instrument is said to be reliable to measure reliable if it has an alpha value greater than 0.6. See the value of Cronbach's alpha and each variable. The level of relativity is generally accepted at a value of 0.6 . Tests whose reliability is below 0.6 are considered unreliable.

Table 2. Values of the reference group variables, brand image, internet marketing, and purchasing decisions.

\section{Reliability Statistics}

\begin{tabular}{|c|r|}
\hline $\begin{array}{c}\text { Cronbach's } \\
\text { Alpha }\end{array}$ & N of Items \\
\hline 832Asset & 16 \\
\hline
\end{tabular}

Table 2, shows that the scores of the acun group statement items, brand image, internet marketing, andcard purchase decisions is reliable and in accordance with the high reliability value of the minimum reliability value of Cronbach's Alpha 0.6.

Data Quality Test Results

For data in the form of questionnaires, validity tests and reliability tests are needed to see data 
quality. This research has passed the validity and reliability tests.

Classical Assumption Test Results The classic

Assumption test is a test of the organization before conducting multiple linear analysis. This research has passed the normality test, multicollinearity and heterocedasticity.

Results of Multiple Linear Regression Analysis

The results of the calculation of multiple linear regression analysis using SPSS 18 are as follows:

Table 3. Results of Multiple Regression

\begin{tabular}{|c|c|c|c|c|c|}
\hline \multirow[t]{2}{*}{ Model } & \multicolumn{2}{|c|}{ Unstandardized Coefficients } & \multirow{2}{*}{\begin{tabular}{|c|}
$\begin{array}{c}\text { StandardizedCoe } \\
\text { fficients }\end{array}$ \\
Beta
\end{tabular}} & \multirow[b]{2}{*}{$\mathrm{t}$} & \multirow[b]{2}{*}{ Sig. } \\
\hline & $\mathrm{B}$ & Std. Error & & & \\
\hline $\begin{array}{l}.330 .000 \\
\text { X1 } \\
\text { X2 } \\
\text { X3 }\end{array}$ & $\begin{array}{r}1,917 \\
.118 .323 \\
-.193 \\
.124 .309 .008\end{array}$ & .075 & $\begin{array}{r}.365 \\
-.241\end{array}$ & $\begin{array}{l}5,814 \\
3,091 \\
-2561 \\
2,697\end{array}$ & $\begin{array}{r}\text { (Constant) } \\
.002 \\
.011 \\
.333\end{array}$ \\
\hline
\end{tabular}

a. Dependent Variable: $\mathrm{Y}$

Based on Table 3, multiple linear regression equations can be obtained as follows:

$$
Y=1.917-365 X_{1}+-193 X_{2}+333 X_{3}+e
$$

From the multiple linear regression equation above, can inform that

1. the constant value is 1.917 , where the value means that if the reference group, brand image and internet marketing together do not experience a change or equal to zero (0), the magnitude of the purchase decision is 1,917 units.

2. The reference group regression coefficient is 365 which means the reference group variable has a positive influence on the purchase decision regression coefficient value means that if the reference group variable increases by 1 unit then the purchase decision will increase by 365 units.

3. Regression coefficient of brand image -193 which means if the brand image variable has a negative influence on the purchase decision variable. This regression coefficient value means that if the brand image variable decreases by 1 unit then the purchasing decision will also decrease by -193 .

Analysis of Multiple Correlation (R) and Determination Coefficient $\left(\mathbf{r}^{\mathbf{2}}\right)$

Table 4. Results of Multiple Correlation (R) AND Determination Coefficient $\left(r^{2}\right)$

\begin{tabular}{|l|r|l|l|l|}
\hline $\begin{array}{l}\text { ModelM } \\
\text { odel }\end{array}$ & $\mathrm{R}$ & R Square & $\begin{array}{c}\text { Adjusted R } \\
\text { Square }\end{array}$ & $\begin{array}{c}\text { Std. Error of the } \\
\text { Estimate }\end{array}$ \\
\hline 1 & $.470^{\mathrm{A}}$ & .206 .55488 & & .221 \\
\hline
\end{tabular}

According to the table above the value of coefficient $(\mathrm{R})$ significantly influence the reference group of independent variables (X1), brand image (X2) and internet marketing (X3) on the purchase decision variables $(\mathrm{Y})$, the value of the coefficient is $0.470>0.5$. Which means that the independent variable reference group (X1), brand image (X2), and internet marketing (X3) significantly affects the dependent variable purchase decisions (Y)

Rated coefficient of determination or Adjust $\left(\mathrm{R}^{2}\right)$ obtained 0.206 , which means that the variable leading independent group reference (X1), brand image (X2), and internet marketing (X3) to the 
dependent variable of purchase decision (Y) of $20.6 \%$ while the remaining $79.4 \%$ is influenced by variables not examined in the study.

\section{HYPOTHESIS}

Test Results F Test

Table 5. F Test Results (Simultaneously)

\begin{tabular}{|ll|r|r|r|r|r|}
\hline Model & & \multicolumn{1}{|c|}{ ANOVA } \\
\hline 1 & Sum of Squares & df & Mean Square & F & Sig. \\
\hline & Regression & $14,780.000$ & 3 & 4,551 & & $13,652^{\mathrm{a}}$ \\
& Residual & 48032 & 156 & .308 & & \\
& Total & 61684 & 159 & & & \\
\hline
\end{tabular}

a. Predictors: (Constant), X3, X2, X1

b. Dependent Variable: Y

Based on table above, it can be seen that the $\mathrm{F}$ value is 14.780 which is greater than $\mathrm{F}$ table 1.557. This means that the location variable (X1) reference group (X2) brand image internet marketing (X3). Simultaneously significant effect on purchasing decisions (Y)

T Test

Table 6. T Test Results (Partially)

Coefficients $^{\mathrm{a}}$

\begin{tabular}{|c|c|c|c|c|c|}
\hline \multirow[t]{2}{*}{ Model } & \multicolumn{2}{|c|}{ Unstandardized Coefficients } & \multirow{2}{*}{\begin{tabular}{|c}
$\begin{array}{c}\text { StandardizedCoe } \\
\text { fficients }\end{array}$ \\
Beta
\end{tabular}} & \multirow[b]{2}{*}{$\mathrm{t}$} & \multirow[b]{2}{*}{ Sig. } \\
\hline & $\mathrm{B}$ & Std. Error & & & \\
\hline $\begin{array}{l}.330 .000 \\
\mathrm{X} 1 \\
\mathrm{X} 2 \\
\mathrm{X} 3\end{array}$ & $\begin{array}{r}1,917 \\
.118 .323 \\
-.193 \\
.124 .309 .008\end{array}$ & .075 & $\begin{array}{r}.365 \\
-.241\end{array}$ & $\begin{array}{l}5,814 \\
3,091 \\
-2561 \\
2,697\end{array}$ & $\begin{array}{r}\text { (Constant) } \\
.002 \\
.011 \\
.333\end{array}$ \\
\hline
\end{tabular}

a. Dependent Variable: $\mathrm{Y}$

1. Reference group (X1)

The value of the calculated $\mathrm{T}$ reference group $(\mathrm{X} 1)$ is 3.091> $\mathrm{T}$ value of 1.557. This shows that the reference group variable $(\mathrm{X} 1)$ partially has a significant effect on purchasing decisions $(\mathrm{Y})$

2. Variable brand image (X2)

The value of the calculated $\mathrm{T}$ brand image variable $(\mathrm{X} 2)$ is $-2.561<\mathrm{T}$ table value 1.557 . This shows that the brand image variable (X2) partially does not have a significant effect on purchasing decisions $(\mathrm{Y})$

3. Variable internet marketing (X3)

Large T value calculated internet marketing variable (X3) is 2,697> T table value 1.557 this indicates that internet marketing (X3) variable partially has a significant effect on purchasing decisions (Y).

\section{Heteroscedasticity Test}

Table 7. Heteroscedasticity Test Results

Coefficients $^{\mathrm{a}}$

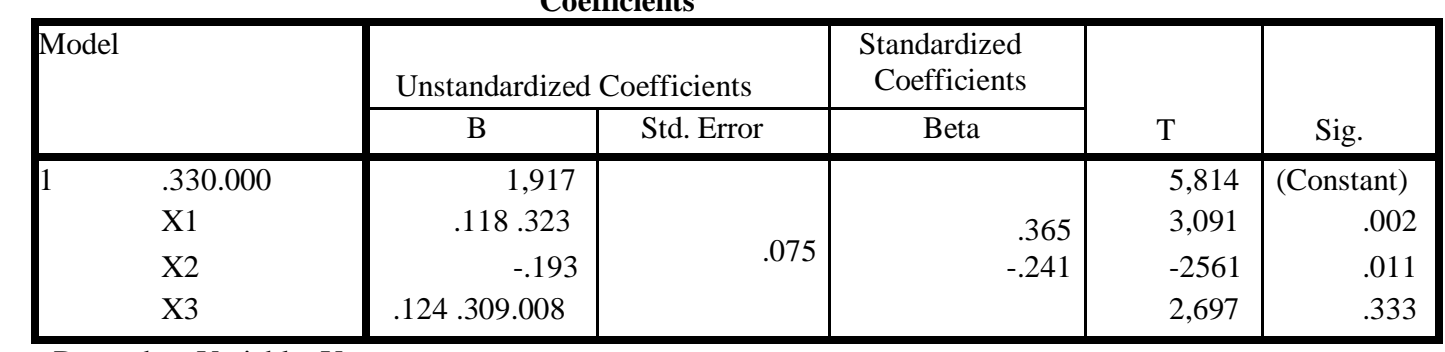

a. Dependent Variable: $\mathrm{Y}$ 
The results of heteroscedaticity testing show the SIG value of the reference group variable (X1) of (0.002), brand image (X2) of (0.011) and internet marketing (X3) of (0.008) SIG variable value> 0.05 in group variables reference, brand image, and internet marketing. This means that the regression model did not occur in the variable heteroskedastisity

\section{Multikoloniearitas Test}

Table 8. Test Results Multikoloniearitas

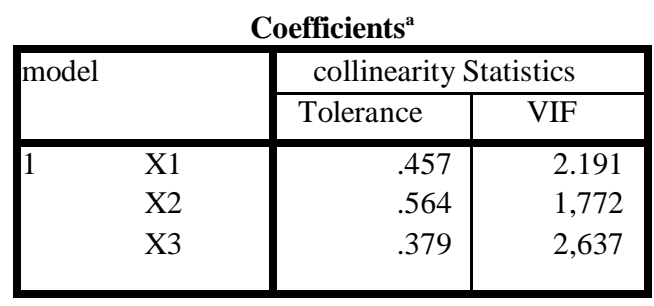

Based on the table above, it can be seen that the regression model is not experiencing multicolonicity disorders. This can be seen in the tolerance value of each independent variable greater than 0.1 , the result of VIF calculation also shows that the VIF value of each independent variable is less than 10. So it can be concluded that there is no multicollinearity between the independent variables in the regression model.

\section{Normality Test}

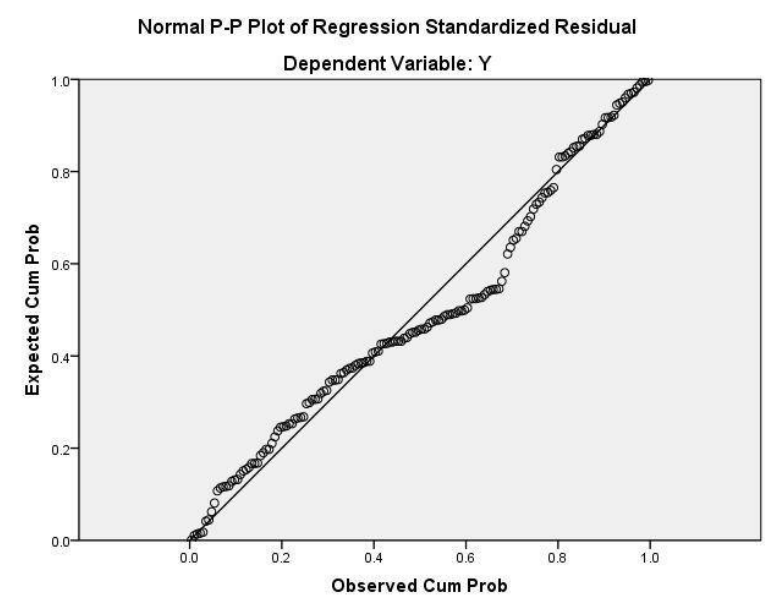

Figure 9. Normality Test Results

From the graph above it is known that the points spread around the diagonal line and follow the direction of the diagonal line, so that the normal distribution data is concluded.

\section{DISCUSSION}

1) The simultaneous influence of reference groups and internet marketing on As card customer satisfaction.

Based on the results of multiple linear analysis, it can be seen that the reference group, brand image, and internet marketing together affect customer satisfaction by $20.6 \%$ according to the coefficient of determination that is adjusted while the remaining $79.4 \%$ is influenced by other variables outside the variable in this study, customer satisfaction can be influenced by 2 factors, namely external and internal factors in this study indicate that external factors have a smaller influence compared to internal factors because communication tools today have become a major need of society. External factors consist of culture, social class, marketing strategy, especially in this study, namely the reference group, brand 
image, and internet marketingwhile internal factors consist of lifestyle, personality, self-concept, motivation, belief and knowledge.

\section{2) Partial influence of reference groups on As card customer decisions.}

The results showed that the reference group had a significant effect

on the As card purchase decision. This means that consumers make As card purchases by considering the suggestions or opinions of the reference groups around them, such as family, friends, and neighbors is the respondent's reference group in observing, discussing, and seeking information about the As card. In the case of the reference group variable, information has an important role in influencing respondents to make purchases on the As card, such as providing information and making the individual aware of the existence of a particular product or brand in this case katu As. By providing detailed information and insights about As cards, often sharing experiences to the invitation to use the As card. The positive sign of the regression model equation shows that the reference group has a positive influence on the As card customer decision.

This is in accordance with the theory of Sumarwan (2011: 305) which says that the reference group significantly influences a person's behavior, for example in the buying process. Then supported by the results of research conducted by Makgosa et al (2007) state a significant influence between reference groups and purchasing decisions.

Based on respondents' answers in this study for the reference group variables, through multiple regression analysis there is a positive relationship between the reference group and customer satisfaction, which is indicated by the regression coefficient of the reference group variable (X1) 0.206 which is positive. A positive sign on regression coefficient represents a unidirectional relationship between the influence of the reference group on the As card purchase decision, so that if the reference group (X1) is positive, the purchasing decision (Y) will increase as well.

\section{3) Partial influence of internet marketingon As card purchase decisions as card purchase decisions}

A positive sign of the equation of the regression model shows that internet marketing has a positive influence on. The partial test results show that internet marketing has a significant effect on purchasing decisions, where thevariable internet marketing has a dominant influence compared to the reference group in influencing the As card purchase decision. Because internet marketing is a partial $\mathrm{r}$ value that is greater than the reference group.

This is related to the respondents in the study showing that the majority of respondents consisting of students and private employees are the majority of women aged between 15-25 years. Where they use more than one provider card other than the As card. But the main card they use as a communication device is the As card. Respondents have several reasons to use the As card to support their daily activities, such as interacting and communicating with friends and community in social media.

\section{CONCLUSION}

\section{Conclusions}

The conclusions of this study are

1. reference groups, brand image, and internet marketing, which have a significant simultaneous effect on As card purchase decisions for students, students, and workers.

2. The reference group has a partially significant effect on the As card purchase decision.

3. Internet marketing has a partially significant effect on As card purchase decisions for students, students, and employees.

\section{Suggestions}

Suggestions given:

1) For researchers

Next researcher is suggested to conduct research outside the independent variables used in this study, for example promotion mix or other marketing mix that can be used to increase customer satisfaction

2) For companies Seeing higher competition in the internet world, in hope that you will always improve the quality and brand that is increasingly loved by the community, so that it can increase customer satisfaction. 


\section{REFERENCES}

[1] Amron, A. (2018). The Influence of Image Brands, Brand Trusts, Product Quality, and Price on the Consumer's Buying Decision of MPV Cars, 14(13), 228-239.

[2] Heriyati Pantri, S. (2015). ANALYSIS OF THE EFFECT OF BRAND IMAGE AND PRODUCT QUALITY ON

[3] CONSUMER PURCHASE DECISIONS ON NEXIAN HANDPHONE. Journal of Business Strategy and Execution, 4(2), 171-205.

[4] Ikechukwu, A., Victor, O., Gerald, N., \& Jeff, O. (2017). Effects of Online Marketing on the Behavior of Consumers in Selected Online Companies in Owerri, Imo State - Nigeria., 6(6), 32 43.

[5] Juhaeri. (2016). THE EFFECT OF INTERNET MARKETING ON TRUST AND ITS IMPLICATIONS ON STUDENT PURCHASE DECISIONS FACULTY OF ECONOMIC PAMULANG ANGKATAN UNIVERSITY OF 2015 WHICH DOES PURCHASE ONLINE THROUGH FACEBOOK SOCIAL MEDIA, 001, 16-28.

[6] Karman, MA (2015). The Impact of Social Media Marketing on Brand Equity toward the Purchase Intention of Starbucks Indonesia, 3(2), 77-88.

[7] Kotler, Philip and Armstrong, G. (2008). Principles of marketing. (Volume 1.). Jakarta: Airlangga.

[8] Kotler, Philip and Keller, Kevin, L. (2009). Marketing Management. Thirteenth edition (Volume 1). Translation by Bob Sabran. Jakarta: Airlangga.

[9] Laksamana, P. (2018). Impact of Social Media Marketing on Purchase Intention and Brand loyalty: Evidence from Indonesia 's Banking Industry, 8(1), 13-18.

[10] Massie, DBMSJDD, \& Tampenawas, JLA (2017). THE EFFECT OF GROUPS OF REFERENCE AND BRAND IMAGE ON INTEREST TO BUY THE INFLUENCE OF REFERENCE SMARTPHONES GROUP AND BRAND IMAGE ON BUYING INTEREST OF, 5(3), 3714-3723.

[11] ShindyRamadiyaniPradita, Y. (2017). Effect of Brand Image and Perceived Price Towards Purchase Decision in Kentucky Fried Chicken (KFC), 36.

[12] Sumarwan, U. (2011). Consumer Behavior: Theory and Its Application in Marketing. Bogor: Ghalia Indonesia.

[13] Warmika, IGK (2017). WOM COMMUNICATION ON THE PURCHASE DECISION OF BALI ALUS SPA.

[14] PRODUCTS Ni Nyoman Kusuma Aditya Dewi 1 Faculty of Economics and Business Udayana University, Bali, Indonesia Developments in the business world have been accelerating and competition is getting tighter, 6(10), 5580-5606.

[15] Yuniarti, Y. (2015). THE EFFECT OF REFERENCE AND FAMILY GROUPS ON THE PURCHASE DECISION OF JAMBI BATIK IN JAMBI CITY, 17. 